\title{
Aquifer structure and contamination risk in lava flows: insights from Iceland and Australia
}

K. Kiernan · C. Wood · G. Middleton

Abstract Relatively recent recognition of the importance of endogenous lava emplacement mechanisms requires updating of groundwater models for some volcanic terranes because voids produced during lava inflation play a more significant role in their hydrogeology than has generally been recognised. Highly integrated, underground drainage systems in some very young lava flows in Iceland exemplify the potentially complex, fissured and conduit aquifers which may exist. Similarities between such aquifers and easily polluted, karstic conduit aquifers suggest greater research and more careful and protective management of some volcanic aquifers are warranted. Interpretation of aquifer structure can be impeded on very old lava flows by superimposition of sediments and accumulation of weathering residues but, if emplacement was by endogenous processes, then relicts of similar void systems may persist and pose similar hazards.

Keywords Groundwater · Fissured aquifer $\cdot$ Conduit aquifer $\cdot$ Lava tubes $\cdot$ Pollution

Received: 16 April 2002 / Accepted: 10 September 2002 Published online: 29 October 2002

(C) Springer-Verlag 2002

\section{K. Kiernan ( $\square)$}

School of Geography and Environmental Studies, University of Tasmania, G.P.O. Box 252C,

Hobart 7001, Tasmania

E-mail: kevin.kiernan@fpb.tas.gov.au

Tel.: +61-3-62337716

Fax: +61-3-62337954

C. Wood

School of Conservation Sciences,

Bournemouth University,

Bournemouth, UK

G. Middleton

P.0. Box 269, Sandy Bay,

7005 Tasmania, Australia

\section{Introduction}

Rapid infiltration leads to very dry conditions on the surface of some volcanic terranes, with even large allogenic streams sometimes sinking underground upon reaching a lava plain. The earliest colonising vegetation on fresh lava flows typically comprises xerophytic species or, in very humid environments, mosses and bolster communities (Johnson and others 1968; Crawford 1992). Unless a clayrich regolith perches water, procurement of an adequate supply may remain problematic. Difficulties may arise in establishing bores because aquifers in hard volcanic rocks tend to be heterogeneous and discontinuous. They are generally unconfined and fissured, their transmissivity is high, and the water table may occur at considerable depth (Davis and De Wiest 1966; Ollier 1969). Springs associated with basalts may be very large (Todd 1980) but are typically restricted to lava-flow margins. Concern has occasionally been expressed regarding the potential for lava-tube caves to facilitate groundwater contamination similar to that afflicting some karst aquifers (Grimes 1999; Halliday 2000, 2001).

This paper comments on new understanding of lava emplacement mechanisms and infers much greater opportunities for transmission and storage of groundwater than previously recognised, illustrating this with observations from very young lava flows in Iceland. Potential implications for aquifer structure and function in similar, young endogenous flows are assessed, based on observations from other basaltic terrains and literature sources. The issue of poor understanding of the nature of flow in basaltic aquifers is discussed and evidence is provided of opportunities for potential pollution hazards. Attention is drawn to the potential for attributes similar to those in a 200 -year-old Icelandic lava flow to persist in older flows, illustrating this and potential management issues, using examples from Australia.

\section{Hydrogeological overview of volcanic terranes}

Ash deposits near volcanic vents tend to be highly permeable and springs may occur downslope due to better sorting of ash with increasing distance from a vent, the 
reduction in pore size promoting water retention by molecular attraction. Alluvial sediments beneath lava flows may also be important aquifers (Ollier 1969). Particularly large springs may occur from pillow lavas where interstices contain secondary minerals. Porosity derived from basalt petrofabric results primarily from vesicles and minor intercrystalline voids. The porosity of volcanic rocks ranges from $<1 \%$ for dense basalt to $>85 \%$ for pumice (Davis and Wiest 1966). Porosity of dense massive lava is typically $1-10 \%$, and $10-50 \%$ for vesicular basalts.

Pahoehoe is generally more permeable than aa (Davis and De Wiest 1966).

Darcian flow cannot be assumed because a variety of larger structures are also important, including pronounced partings between lava layers and cooling contraction cracks. Sen (1995) attributes hydraulic conductivities of up to $10^{4} \mathrm{~m} /$ day to vesicles and cooling contraction cracks. Post-eruptive fissuring is also common in tectonically active areas. Aquifers are not generally confined to separate lava flows where vertical fractures are well developed (Fetter 1988). Only minor peripheral spaces are formed around undrained lava tubes when they cool and contract, but large voids may remain when lava tubes drain. Such lava-tube caves have generally been regarded as of limited, overall significance although some have been used to gain access to groundwater, with municipal waterworks having been constructed in one cave on Terceira, Azores, and dams constructed on streams in lava caves in Utah and Hawaii (Ollier and Brown 1965; Kiernan 1982; Webb and others 1982; Halliday 2001).

Only two rivers maintain a north-south surface course across the $12,000-\mathrm{km}^{2}$ lava plains of western Victoria, Australia, and all rivers which descend along $320 \mathrm{~km}$ of the northern edge of the Snake River Plain, Idaho, USA, sink into lava before rising from large springs (Ollier 1969). Such springs are commonly assumed to be fed by infiltration into joints and fissures which is deflected laterally along the base of the flow, voids between flow units or relatively impermeable palaeosurfaces (Ollier 1969; Kulkarni and others 2000; Kambesis 2000). The 3,000-mthick lava sequence of the Columbia Plateau is so broken up in some zones as to be practically a rubble, with gas bubbles, lava tubes and small caverns adding to the porosity and storage capacity, and permeable gravels and sands occurring between lava layers (Johnson Division 1966). Wells in the top $300 \mathrm{~m}$ of these lavas yield 216,000 $432,000 \mathrm{l} / \mathrm{h}$ (Fetter 1988), a productivity which Todd (1980) attributes to a high permeability permitted by lava tubes and shrinkage cracks. Some have suggested the most important structures permissive of transmission and storage are, in order, interstitial spaces in clinkery lava at the tops of lava flows, cavities between lava beds, shrinkage cracks, lava tubes, vesicles, fissures resulting from faulting and cracking after rocks have cooled, and tree moulds (Maxwell and Hacket 1963; Todd 1980).

Permeability may change over time. Large caves occasionally form due to piping of volcanic ash (Kiernan 1982). Ongoing tectonism, loading or unloading may cause further fracturing of basalts, as illustrated by a fissure swarm metres wide through lava fields created by a large earthquake in Iceland in early 2001. Some void widening may also occur due to stream erosion or dissolution of minerals, as in the case of a stream cave $1 \mathrm{~km}$ long and up to $14 \mathrm{~m}$ wide and $17 \mathrm{~m}$ high on the eastern slope of Mauna Kea, Hawaii (Werner and others 2000). Few, large erosional stream caves of this kind have been reported from basalts, however, suggesting that the largest void systems are likely to remain primary structures. A greater volume of surface runoff is often evident from older lava flows, suggesting that infiltration is progressively inhibited by the in-washing of sediment (Sen 1995). Bore yields from aquifers in weathered basalts are often significantly lower than those from less-weathered basalts, consistent with infill by weathering residues which have a greater mass than the original rock. However, bore yields and spring discharge sometimes remain high, and rapid rises in discharge after rainfall, followed by rapid recession as transmissibility and hydraulic gradient decline sometimes suggest only limited storage (Kambesis 2000). Such attributes may suggest an aquifer structure more akin to an open, urban storm-water drain system than one involving progressive release of water from very small voids. However, discharge through buried gravels and sands may be very high.

\section{Void systems in tube-fed lavas}

Some deficiencies in knowledge of lava-flow hydrogeology probably result from incomplete understanding of lava emplacement processes and their implications for bedrock structures. New understanding of lava emplacement mechanisms suggests the relative significance of these structures warrants reconsideration in updating hydrogeological models. Formerly, large lava flows were thought to have been emplaced by rapid and turbulent flood events (Shaw and Swanson 1970). In recent years there has been increasing recognition of the importance of endogenous lava emplacement, whereby lava moves forwards over low-gradient slopes not as single, rapid flood events but as successive, sheet-like flow units fed by internal tubes of lava (insulated beneath congealed surface crust). This enables flow injection under hydrostatic pressure (Hon and others 1994; Self and others 1996), although the precise relationship between the formation of sheet flow units and lava tubes is not entirely resolved. In addition to leaving a legacy of distinctive surface landforms, this process may leave large subsurface voids including major fissures and drained lava tubes. Re-evaluation of the emplacement processes applicable to many lava flows previously regarded as flood basalts remains in its infancy, and hence potential hydrogeological implications have received relatively little attention. Given the acknowledged hydrogeological importance of such structures at a local scale (Todd 1980; Halihan and Wicks 1998), it follows that if endogenous emplacement was more widespread than previously recognised, then they may be of greater overall 
significance to basalt hydrogeology than is commonly recognised.

Where lava flows are emplaced by endogenous mechanisms, conventional cooling contraction cracking is supplemented by very abundant, brittle fracturing which occurs when congealed lava crust is raised or lowered by hydrostatic pressure (Walker 1991; Halliday 1998a, 1998b). Many fissures produced by inflation and deflation, together with later patterns of weathering, erosion and cavern breakdown conditioned by such legacies of endogenous emplacement, assume considerable significance as infiltration routes. There remains a lack of definition in the literature concerning the shape and pattern of internal lava pathways produced by endogenous emplacement. Not all lava caves necessarily assume the discrete, subcylindrical form to which the term lava tube is most appropriately applied, and some may be the product of relatively fluid injection into and beneath older flow units (Wood and others 2001). Nevertheless, the great volume of some lavatube caves highlights the significant quantities of groundwater which may be transferred or stored (Fig. 1). Prime facie it would seem that groundwater could flow considerable distances through drained lava tubes, as suggested by the $42-\mathrm{km}$, end-to-end length of Kazumura Cave on Kilauea Volcano, Hawaii, in which over $65 \mathrm{~km}$ of underground passages has been explored (Kambesis 1995). There is some evidence for lava-tube caves playing such a role. For example, some Hawaiian caves are invaded by permanent or episodic streams or contain fluvial deposits, and large springs emerge from caves or from offshore springs which suggest conduit flow (Stearns and McDonald 1946; Kambesis 2000; Halliday 2001). In Mauritius, underground drainage through the extensive Plaine des Roches lava tubes also forms seaside springs (Middleton and Halliday 1997). In the USA the Rogue River, Oregon, and some other streams also invade lava-tube caves. In western Samoa the Pala River sinks underground into a 20-m diameter hole in its bed, from which it flows underground for $1 \mathrm{~km}$ through the Pe'ape'a Cave lava tube in which it has cut erosion grooves, scallops and plunge pools and deposited pebbly alluvium (Ollier and Zarriello 1979). Natural bridges in Northland, New Zealand, appear to

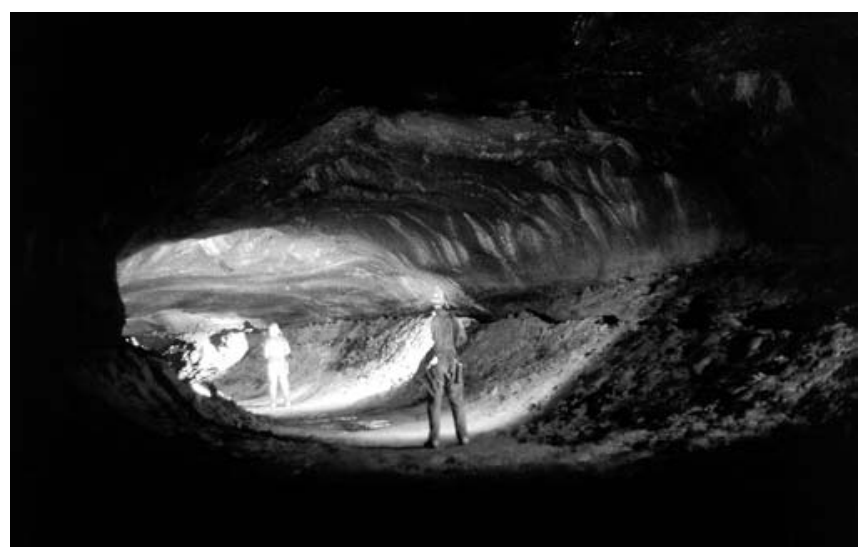

Fig. 1

Large volume of Surtshellir lava-tube cave, Iceland have resulted from infiltration of water down joints into lava tubes which have subsequently collapsed (Hemming 1979). To the east of Bobakilandy in far north-western Madagascar, a stream flows through a gorge bridged by natural arches which also appear to be residual from collapse of a lava-tube cave.

The accessible portion of many lava-tube caves terminates in an abrupt seal of undrained lava. Large, drained lava tubes may continue for long distances beyond very short lava seals (Wood and others 2001) but the availability of alternative void networks permissive of water flow around lava seals will influence the potential for long, underground stream systems. Many lava caves are formed through a sequence of sheet and tongue-shaped flow units separated by voids a few millimetres to a few centimetres high. Although obviously of much smaller capacity than many lava caves, these laterally extensive spaces often have ample capacity to allow high-volume turbulent water flow to bypass lava seals. In some cases they are closed by molten wall and ceiling linings within caves, although later partial collapse may reopen them.

Although lava-tube caves and related structures clearly have the capacity to play a significant groundwater role under some circumstances, few lava caves contain streams or significant volumes of sediment, suggesting alternative void networks allow water to bypass them. The circumstances under which some lava-tube caves may be hydrogeologically significant, and the extent to which alternative pathways may themselves facilitate karst-like aquifer vulnerability remain poorly understood.

\section{Aquifer structure and function in some young, Icelandic lava flows}

The 1783-1784 Laki or 'Skaftár Fires' eruption in southern Iceland was the largest in historic time, emplacing $\sim 14.7 \pm 1 \mathrm{~km}^{3}$ of lava from a row of fissures extending over $40 \mathrm{~km}$ south-westwards from the Grímsvötn Volcano, $13 \mathrm{~km}$ of the fissure line lying beneath the $8,400-\mathrm{km}^{2}$ Vatnajökull ice cap (Fig. 2; Thordarson and Self 1998). In the Hverfisfljot Valley, where the lava is known as the Eldhraun, landforms produced by lava inflation are numerous and include many shallow lava-tube remnants and, near the toe of the flow, an extensive field of large depressions which are probably lava-rise pits. Huge posteruption fractures also cross the flow lobes on the coastal plain (Wood and others 2001, 2002). Considerable volumes of water sink into the lava (Fig. 3).

\section{Bare lava terrane}

An instructive suite of lava inflation structures which plays an important role in the local hydrogeology occurs adjacent to Laufbalavatn, a small lake formed against the western edge of the Eldhraun. Easy ingress for surface water is provided though many cave windows, collapse trenches and collapse depressions. More diffuse infiltration is facilitated by a variety of well-developed fracture 


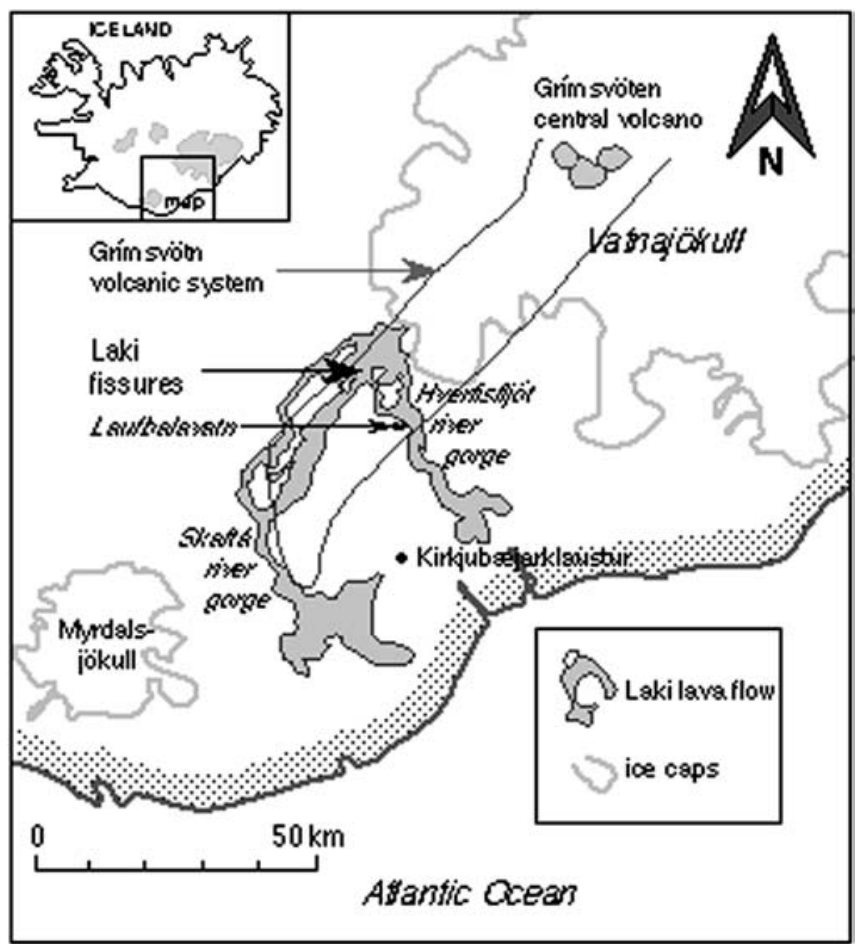

Fig. 2

Location of the Laki lava flows, Hverfisfljót Valley and Laufbalavatn area

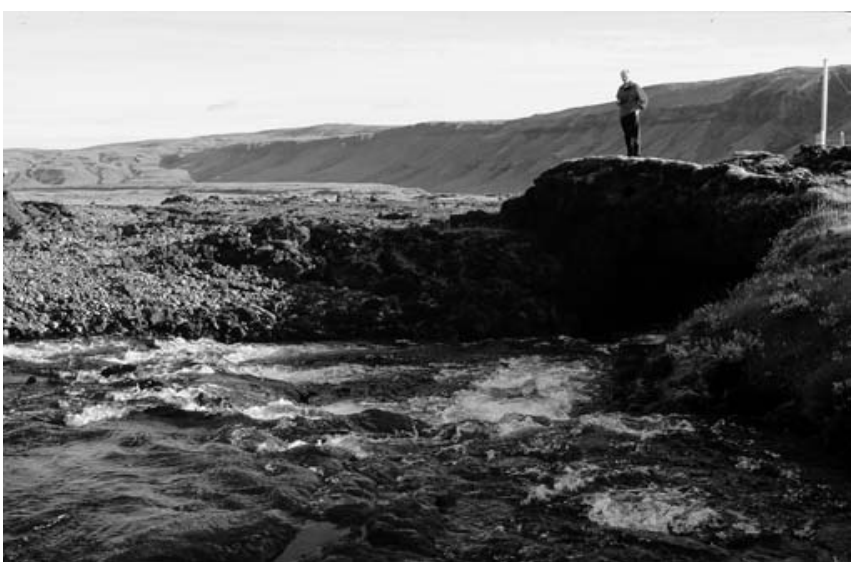

Fig. 3

Water sink in the lower Hverfisfljót Valley, $\sim 12 \mathrm{~km}$ downvalley from Laufbalavatn. The marginal Oðulbrúara River flows for $50 \mathrm{~m}$ through a lava-tube cave before resurging from a turbulent pool

systems associated with lava rises, lava-rise pits, flat pavements, surface sags, deflated and collapsed domes, and a surface breakout of apparently more viscous lava with pronounced, surface pressure ridges. A complex of lava-tube caves in their original or partially collapsed form, totalling nearly $4 \mathrm{~km}$ in length yet contained within an area of only $\sim 0.3 \mathrm{~km}^{2}$, was explored and mapped on the eastern margin of Laufbalavatn in August 2000 (Fig. 4). A similar length of passage was discovered nearby during the following field season (Wood and others 2001;

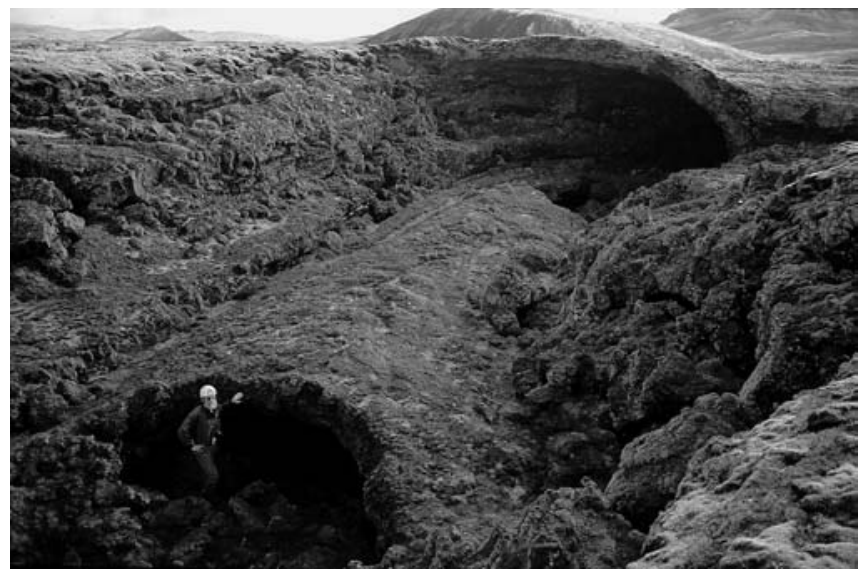

Fig. 4

Collapse depression and cave entrance adjacent to Laufbalavatn, showing a tube-in tube formed by more recent flow of lava than that which formed the larger, partly collapsed tube in which it occurs

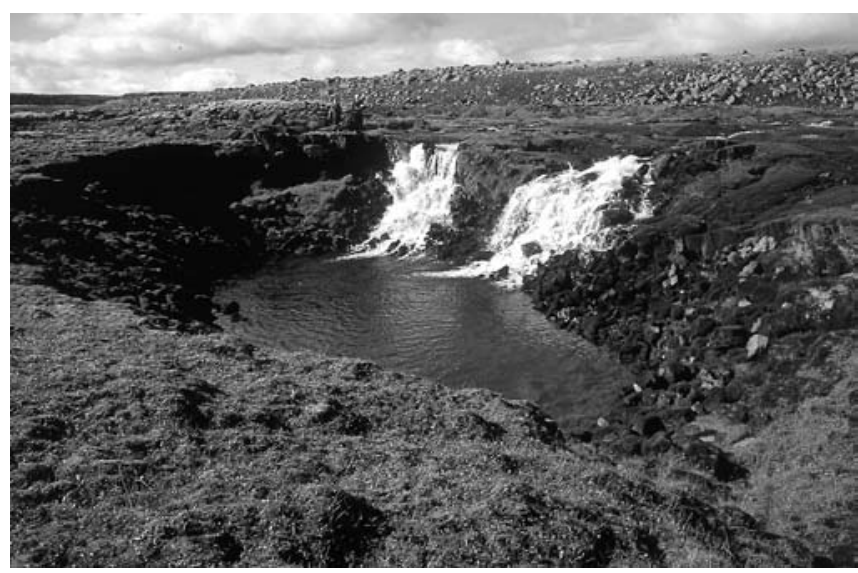

Fig. 5

Main stream sink on the outlet river from Laufbalavatn

Middleton and Kiernan 2002). Many fractures are demonstrably or potentially contiguous with lava tubes. For example, a linear cavity in the surface crust, representing a remnant perimeter passage beneath one deflated dome, connects through lava drain holes to a deeper cave passage and, at an even deeper level, with one of the main passages of the Iðrafossar lava-tube cave system $\sim 8 \mathrm{~m}$ below.

A river which drains the lake pours into a steep-sided collapse depression $160 \mathrm{~m}$ downstream (Fig. 5), the capacity of which was not exceeded during one observed summer flood. Two anabranches which bifurcate a short distance above it sink into separate collapses. Under moderate summer discharge, water also leaks into minor lava tubes and fractures nearer the lake. Under flood conditions, their capacity is exceeded and the river spills into a deflated basin and the lava cave Matargat, when rapidly flowing, underground streams preclude safe human access to both the Matargat and Lykkjuhellir caves. Numerous other water sinks occur along the lake edge, some of which can be identified from small whirlpools. 


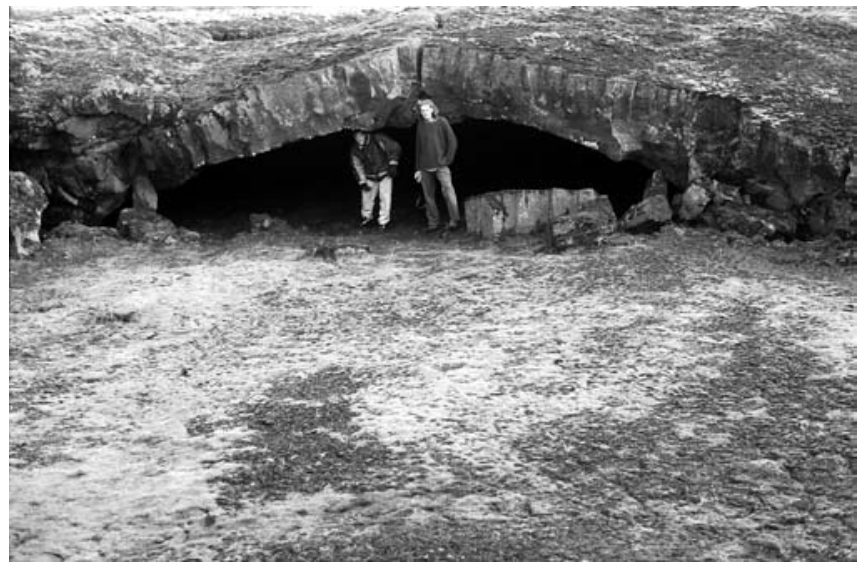

Fig. 6

Overbank silt partially filling a lava tube beside the river upstream from Laufbalavatn

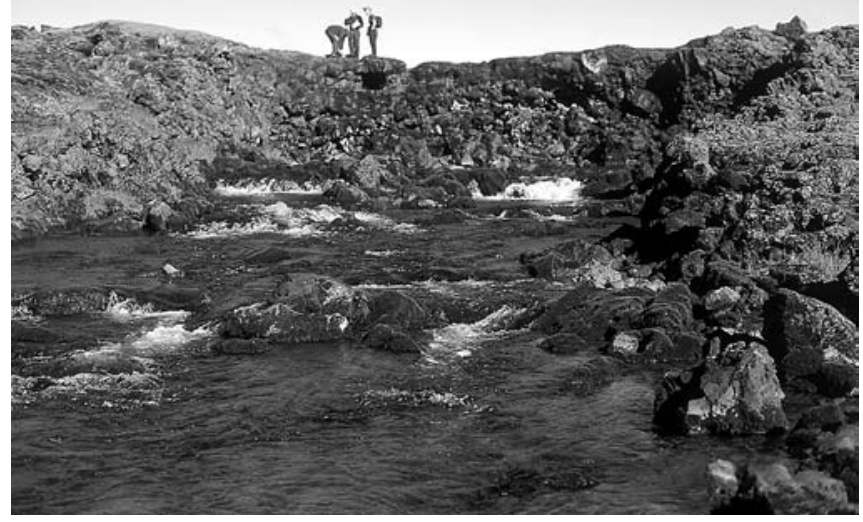

Fig. 7

Spring downvalley from Laufbalavatn

Upstream from the lake, silt deposits adjacent to a marginal river indicate overbank flooding into lava caves (Fig. 6). However, most accessible caves contain only minor seepage. Only those caves closest to the margin of the lava flow carry streams under base flow conditions, discharge from the lake and river spilling into other caves only slightly more distant from the flow edge even during floods.

The main water sink on the river appears to be the source of a large spring which emerges $175 \mathrm{~m}$ to the south from the foot of a low cliff, in the top of which is a dry, surficial lava tube (Fig. 7). One of the largest of the lakeside water sinks is believed to be the source of curtains of water which cascade spectacularly into the western branch of the lava-tube cave Iðrafossar, $525 \mathrm{~m}$ upvalley from the spring (Fig. 8a). The resulting cave stream appears in two other accessible passages and nourishes a small, underground lake (Fig. 8b). Another substantial lakeside water sink $660 \mathrm{~m}$ up-valley probably also feeds the main spring. A smaller spring further west is believed to originate from the westernmost anabranch of the lake outlet stream via
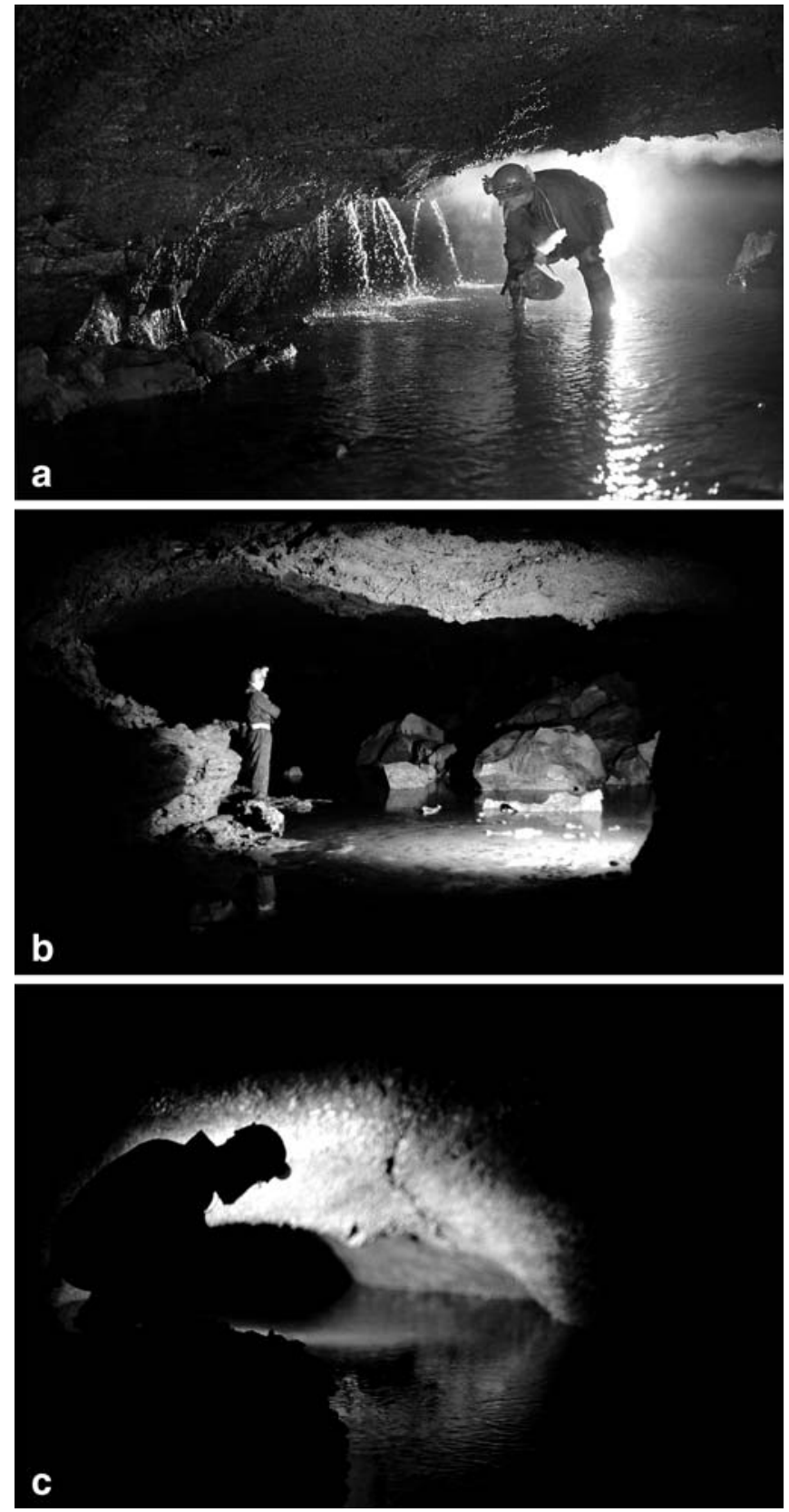

Fig. $8 a-c$

Some underground watercourses in the Laufbalavatn lava tubes. a Water from Laufbalavatn cascading into the Iðrafossar. b Underground lake chamber in Iðrafossar. c Small underground stream passage in Lykkjuhellir

Lykkjuhellir (Fig. 8c), implying an underground course over a distance of $\sim 120 \mathrm{~m}$ as the crow flies.

Downstream from the springs, the river follows a surface course around the margin of the surface lava breakout before sinking again in a deep, elongate pool $305 \mathrm{~m}$ to the south (Fig. 9). Flood overflow occurs through a low point $75 \mathrm{~m}$ upstream of the pool, from which a shorter, muddy channel also conducts floodwaters $60 \mathrm{~m}$ eastwards into the toe of the lava breakout. Sediment in the base of a trench $100 \mathrm{~m}$ further east suggests it is filled from beneath during floods. A deep, isolated pool occurs $50 \mathrm{~m}$ 


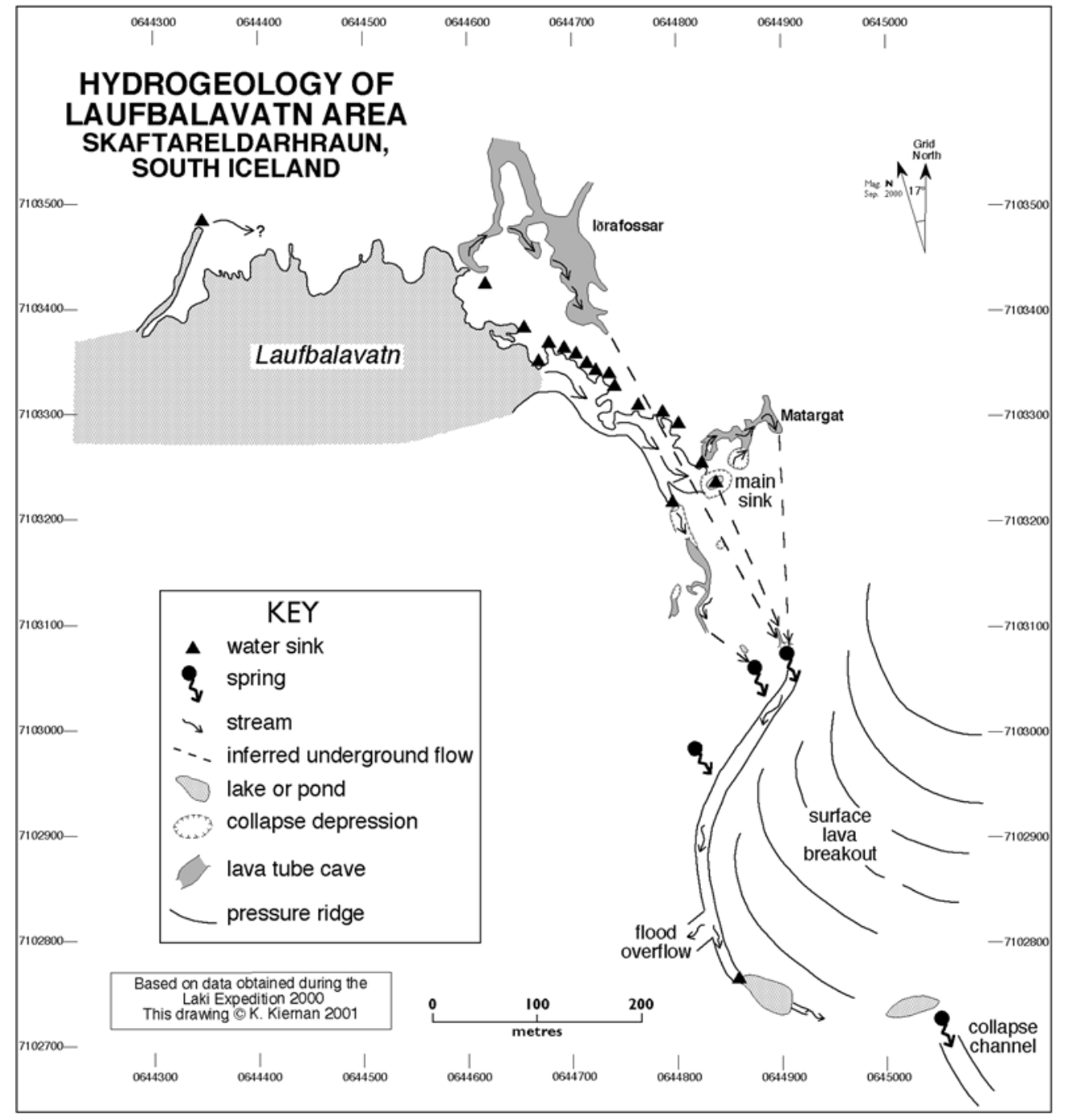

Fig. 9

Water sinks, lava tubes and inferred underground flow paths in the Laufbalavatn area beyond it between pressure ridges. A small overflow spring from beneath the toe of the lava breakout becomes active during floods. All overflowing waters re-infiltrate the lava surface within a few hundred metres, upflow of a lava-tube collapse trench. No evidence was detected of the river reappearing within this $2-\mathrm{km}$-long trench or elsewhere on the surface of the lava flow.

\section{Sediment-mantled lava}

Laufbalavatn forms a sediment trap which inhibits entry of all but the finest sediment into water sinks but, under flood conditions, higher volumes of sediment are introduced into fissures and collapse pits such as those behind Matargat, with the result that silt coats the floors and walls of some caves. Transmission of these sediments through the aquifer with minimal filtration is indicated by the alluvial deposits through which some springs emerge, and which floor surface ponds and flood overflow routes marginal to the lava breakout. Overbank sand and silt deposited by a marginal stream which enters Laufbalavatn locally inhibit diffuse infiltration but subsurface voids remain open (Fig. 6). Nearer Vatnajökull the largest collapse

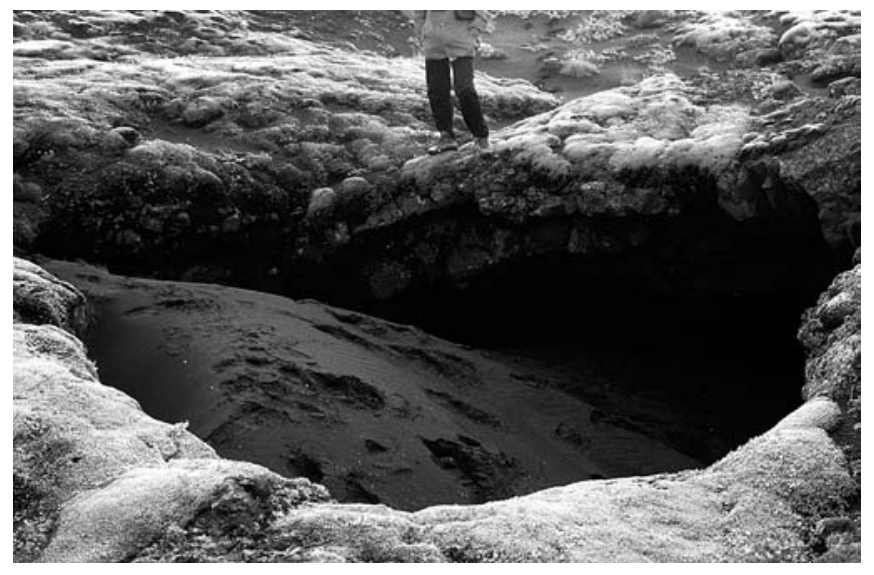

Fig. 10

Glacio-aeolian sediment in lava-tube collapse north-east of Laufbalavatn

depressions are filled with aeolian sediment (Fig. 10). Ultimately, little surface lava protrudes but occasional, conical depressions a few centimetres across indicate 


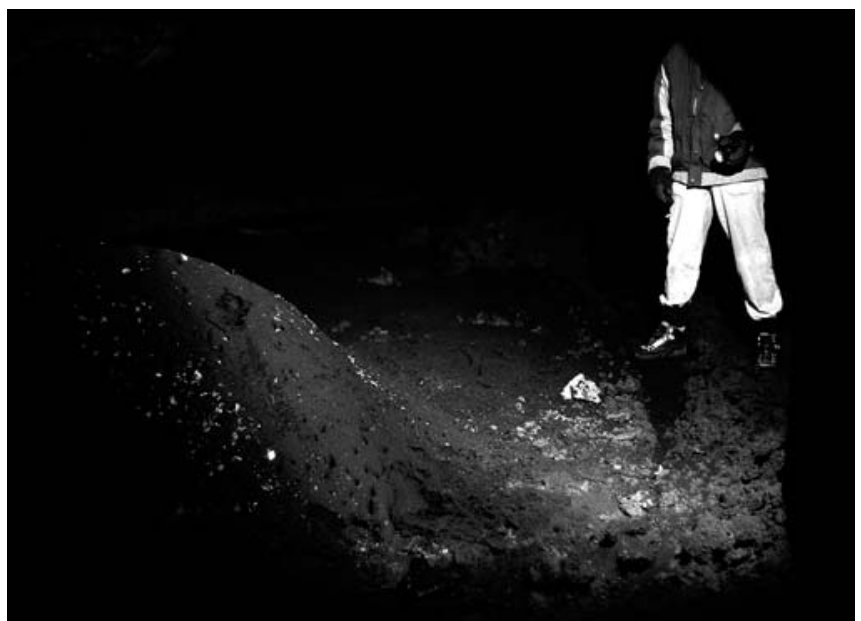

Fig. 11

Small sand cone formed beneath roof fissure in Rauðsteinshellir

sediment loss into crevices. The cave Rauðsteinshellir which occurs in this area is generally $\sim 2-3 \mathrm{~m}$ high, $\sim 3-$ $4 \mathrm{~m}$ wide, and it can be followed for $\sim 700 \mathrm{~m}$ to plugs of undrained lava at either end. Whereas larger sediment accumulations occur in its more open entrances, only small sediment cones occur beneath a few ceiling fissures (Fig. 11). Hence, water still infiltrates the cave despite sediment mantling the lava surface, yet there has been only limited entry of sediment underground. Still nearer the ice cap, a widespread sediment apron perches some meltwater floods, but the lava proximal to it remains sufficiently permeable to absorb even major jökulhlaups caused by catastrophic failure of large, subglacial reservoirs which develop in response to volcanic activity beneath the ice cap (Kaldal 2001). The large, 900-m-long cave Hlauphellir also receives discharge from a seasonal lake $\sim 400 \mathrm{~m}$ in diameter (Fig. 12). Sand occurs in open cave passages between collapse entrances, with sticky clay deeper inside.

\section{Interpretation and comparisons with some other, young lava flows}

The Laufbalavatn area lies in a cul-de-sac which was initially isolated from the main axis of flow down the Hverfisflót Valley by an older volcanic cone, $500 \mathrm{~m}$ south-east of the lake and around which the lava flooded. Initial emplacement of lava into this area stagnated but subsequent downvalley surges of mobile lava from new fissure vents injected fluid lava under earlier congealed crust, initiating the labyrinthine cave system. The tube system matured and permanent flow routes through it were created only when the lava broke across the divide between the lake and cone (Wood and others 2001). The overall hydrogeology involves the integration of drainage through lava tubes with flow through a variety of other structures, consistent with the hydrogeological importance accorded by Davis and De Wiest (1966) to fractures caused by buckling of partly congealed lava. The diversion of both lava tubes and subterranean streams at Laufbalavatn around the surface lava breakout, forcing a temporary
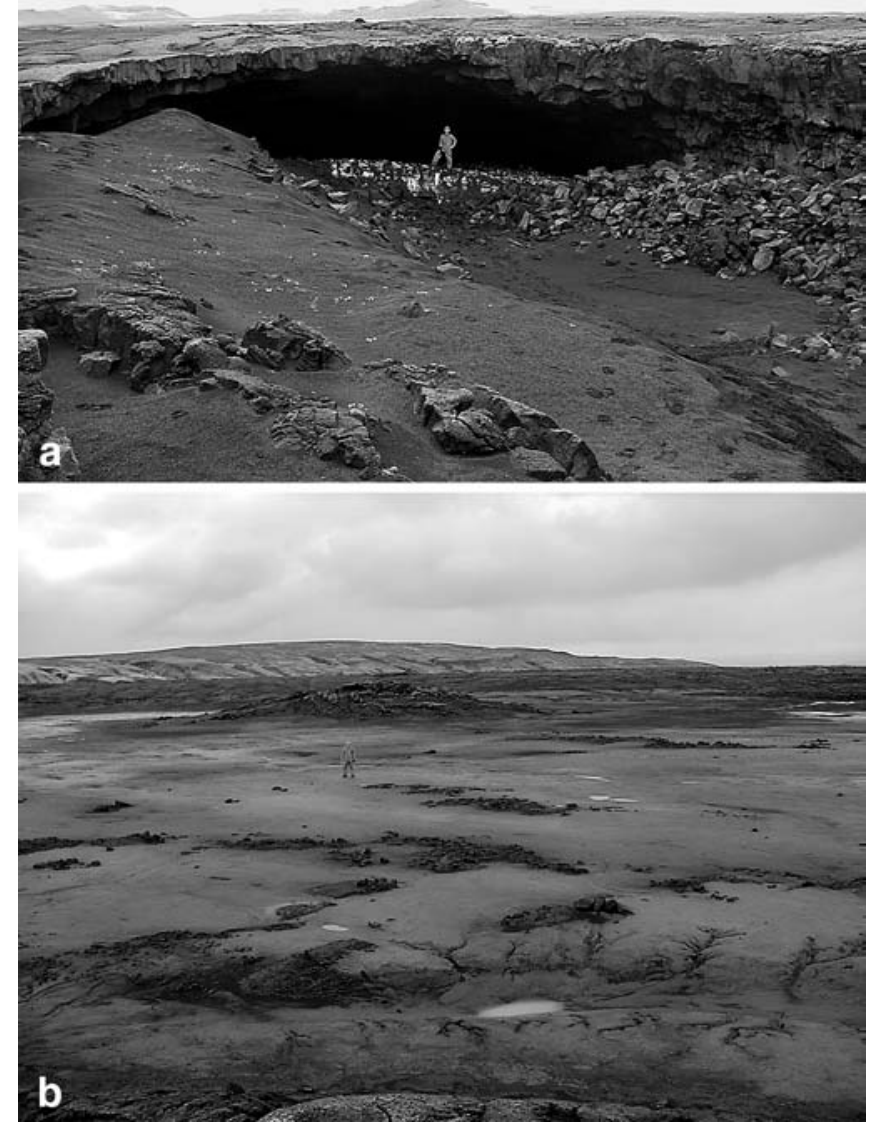

Fig. 12

a Entrance to Hlauphellir, a large lava-tube cave which receives massive, episodic jökulhlaup discharge, and seasonal discharge from b a large ephemeral lake

reversion to surface drainage, highlights the potentially complex hydrogeology which may result from structures produced by various interacting mechanisms of lava emplacement. Hence, these observations confirm the potential hydrogeological significance of structures produced by inflation and deflation processes and indicate that, although lava tubes are by no means a prerequisite for rapid transmission of groundwater through lava flows, under some circumstances they may be of considerable significance.

The caves beside Laufbalavatn are not of large dimensions compared to some lava tubes elsewhere, but their labyrinthine nature is such that the overall void ratio in the basalt could hardly be higher without threatening much more widespread ground surface collapse (Fig. 13). Void density is so great that no discernible pattern was obtained during magnetometer surveys over the cave Völundur. By contrast, magnetometer surveys over the large SurtshellirStefánshellir lava tubes in the $200-\mathrm{km}^{2}$ Hallmundarhraun, west-central Iceland, have revealed well-defined, linear voids (Fig. 14). Despite the more focused tube formation in the Hallmundarhraun, once again numerous other fractures have also been produced by lava inflation 


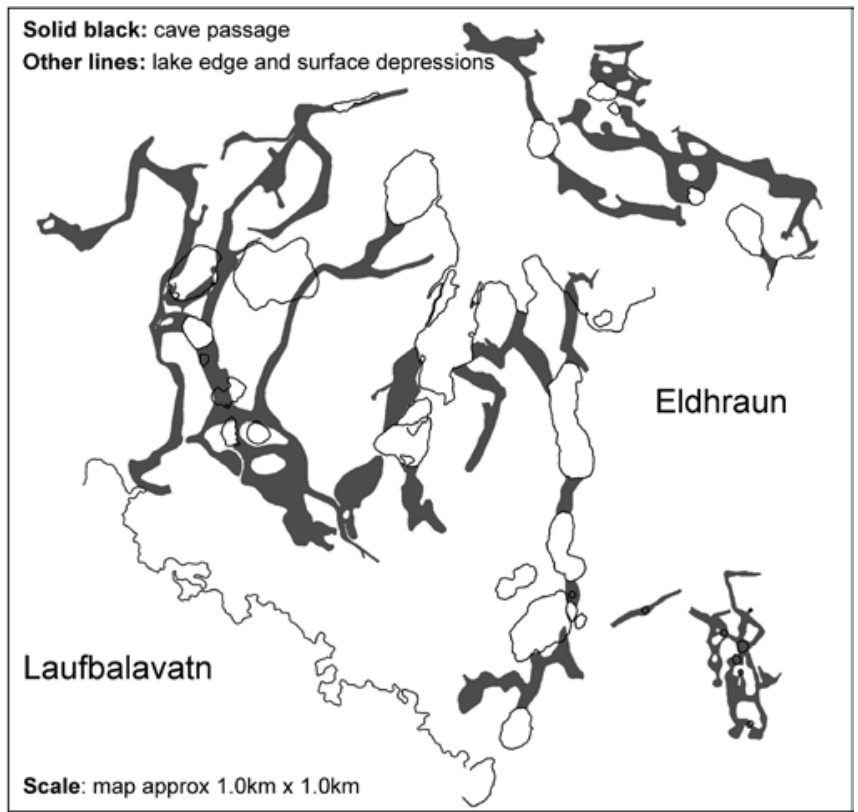

Fig. 13

Distribution of lava-tube cave passages, depressions and surface trenches beside Laufbalavtn

processes there (Fig. 15), and an absence of cave streams indicates abundant, alternative infiltration routes, notwithstanding some ponding which is accentuated by freezing of standing water in caves which form cold-air traps. Large springs at Barnafoss, situated at the lava-flow terminus, suggest that water rapidly reaches the base of the lava (Fig. 16).

The capacity of lava to absorb large volumes of water without lava-tube caves functioning as stream conduits is equally evident from many other, young, tube-fed lava

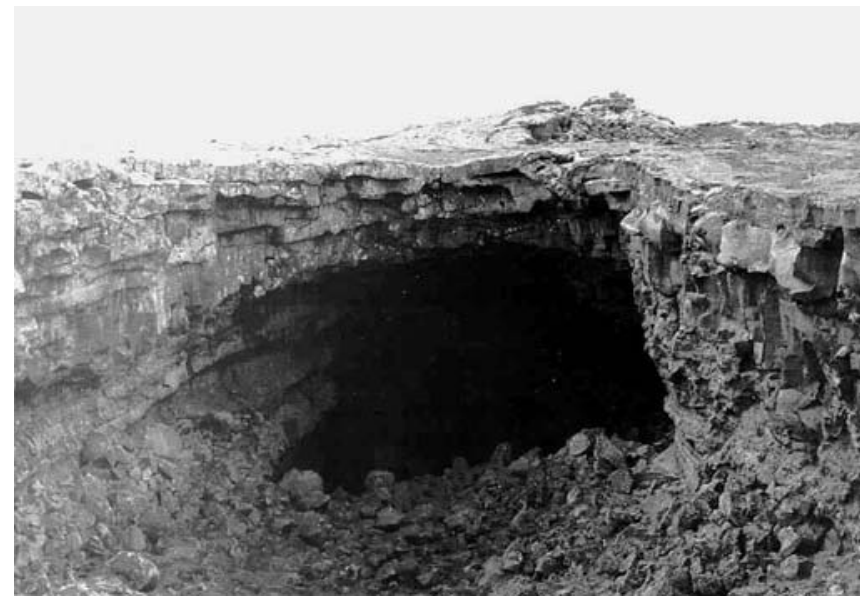

Fig. 15

Collapse window over the lava-tube cave Surtshellir, west-central Iceland; showing highly jointed and cavernous structure, comprising superimposed, sheet-like flow units overlying the cave and within which the original lava tube was formed. The surface tumulus has been caused by up-arching of the crust of the surface flow unit and apparently was not directly connected to the master lava tube

flows. However, as at Laufbalavatn, back-flooding sometimes occurs into caves which do not usually contain streams when heavy rain causes the capacity of deeper voids to be exceeded. For example, in Kaumana Cave, Hawaii, a stream which is audible beneath the floor during rainy conditions, possibly perched upon an ash layer, overflows into the main lava tube, creating hazardous floods when rainfall is very heavy. Water discharges 'like a fire hydrant' onto a street after heavy rain (Kambesis 1995, 2000). The highly integrated structure of the subsurface drainage at Laufbalavatn resembles some karst drainage systems but is more complicated. That streams are less commonly

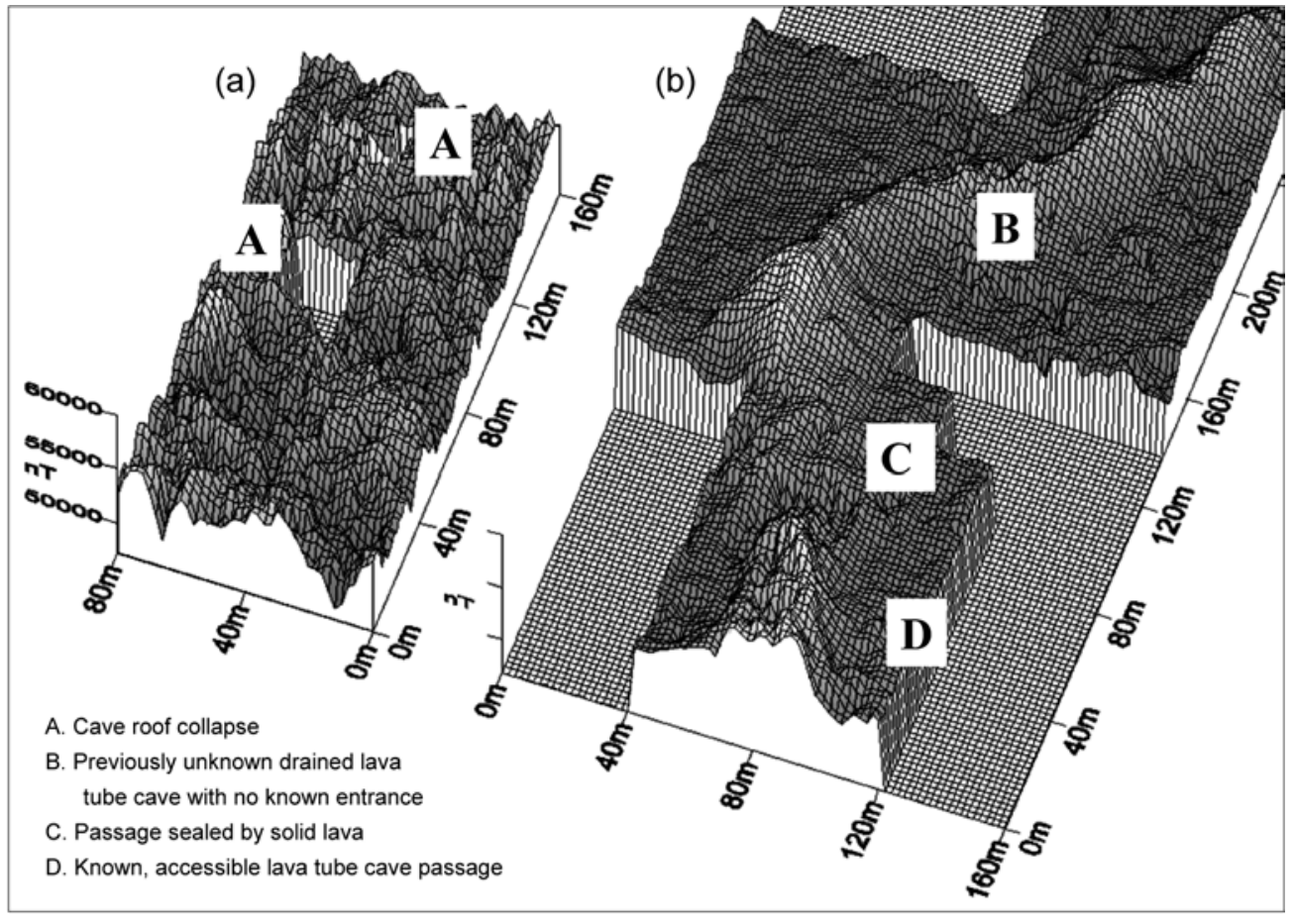

Fig. 14

Contrasting cavity densities in a the upper Eldhraun, southern Iceland, and $\mathbf{b}$ the Hallmundarhraun, west-central Iceland, as revealed by magnetic surveys (survey data courtesy of Paul Cheetham, Laki Underground 2001 expedition). Magnetic surveys at each site were undertaken using the same equipment and method. The high level of 'noise' in a probably results from a lava structure interrupted by a high number of small cavities. By contrast, the pattern of anomalies in $\mathbf{b}$ reveals a single, dominant lava-tube cave passage 


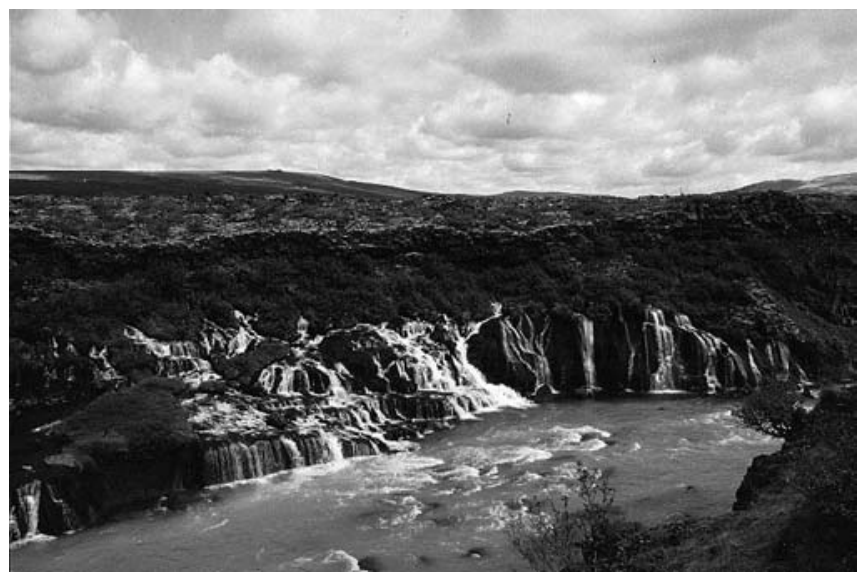

Fig. 16

Springs emerging into the main river from beneath the Hallmundarhraun at Barnafoss

encountered in lava caves than in karst caves probably reflects contrasting modes of void evolution. The primary fissure system in basalts is generally more open than in limestone in which fissures must be widened by solution before significant infiltration is possible. The density of primary fissures in basalt is higher, and water quickly reaches the base of a lava mass, flowing through lava-tube caves and other voids only as a temporary diversion, unless sediment or a lack of jointing renders the cave floor impermeable. Too close an analogy with karst environments should not be drawn because in karst environments voids are extended slowly downwards as streams incise, lowering the water table and leaving higher-level passages which have been abandoned by streams, whereas in highly fractured lava the youngest voids occur nearer the surface and are formed almost instantaneously as successive, new lava flows are superimposed. These new voids allow infiltration to a water table which is likely to already be at the base of the lavas or deep within the lava sequence. Water flows through basalt therefore tend to be less concentrated and erosive than in karst. The deepest voids in lava flows are generally not accessible to cave explorers and hence have not been as widely reported as have deep karst caves, although their existence is confirmed by the high degree of cave adaptation shown by some invertebrates which inhabit very young lava flows and which have migrated upwards from faunas which evolved at greater depth (Crawford 1992; Howarth 1996). If the hydrological role of younger, shallower lava-tube caves appears to be simply the interception of relatively minimal volumes of infiltration water and its immediate transmission down to deeper, pre-existing voids, the question arises as to the circumstances which cause some lava-tube caves to play a more significant hydrogeological role.

Major fissures and lava tubes will always provide important reservoirs and preferred pathways for groundwater flow in the phreatic zone. Within the vadose zone, lava caves are generally bypassed or fail to significantly deflect infiltration towards the base of a lava flow, forming preferred pathways only where subjacent voids are insufficient to accommodate descending water. The latter may occur where lava beds contain dense, unfractured rock with a low effective porosity, as appears to be the case at Andranomiditra Cave, north-western Madagascar, where a seasonal stream flows underground for about $2 \mathrm{~km}$ through lava which displays limited vertical fracturing. Lava caves may also contain streams where ash beds impede infiltration, as at Kaumana Cave, Hawaii, or where thin lava overlies relatively impermeable palaeosurfaces, as may be the case at Laufbalavatn. They may also be important where very large volumes of allogenic water are initially transferred underground as major rivers discharge into lava-filled valleys, as at Laufbalavatn and elsewhere in the Eldhraun and Hallmundarhraun, or where rainfall is very intense, as in Hawaii. Caves which generally lack streams may at other times form flood overflow routes, as illustrated by the hazardous floods in Kaumana Cave. That episodic discharge may be torrential is illustrated by a large tree trunk deposited high in the Antranovato lava cave, east of Bobakilandy in NE Madagascar, when the adjacent river overflowed into it.

\section{Some potential management implications}

Given their fissured or conduit structure, aquifers in young lava flows emplaced by endogenous processes are likely to be vulnerable to contamination. Aquifers in deep leads of alluvial sediment beneath lava may sometimes also be at risk, given rapid recharge through open voids. Examples of young basaltic aquifers at risk include those associated with a number of Mauritian lava caves in which domestic rubbish is dumped and in which human and animal wastes occur (Middleton 2000). Pools in the entrances to some Easter Island lava caves have become fouled by livestock (Kiernan 1982). Rubbish has been disposed of into entrances to the biologically important, 18-km-long Cueva del Viento in the Icod area, Tenerife, where pollution of water by agricultural chemicals and sewage continues to be an issue (Hernandez and Oromi 1996).

In Hawaii, suburban storm waters are diverted into Kaumana Cave, and considerable refuse has been dumped into its entrances, with scrap metal, car parts, plastics, batteries, medical waste, pesticide containers and other material strewn along several hundred metres of stream passage (Kambesis 2000; Halliday 2001). Floodwaters from a subdivision were diverted into one, culturally significant cave and water diversions carried petroleum wastes underground in the Puna caves area. Leakage into these caves from septic tanks has also been reported, aquifer degradation being compounded by the disposal of solid wastes and animal wastes (Halliday 1995). Septic-tank discharge and grey-water wastes which enter the world's longest, known lava tube, Kazamura Cave, rapidly infiltrate cracks in the floor. Groundwater contamination is evident at shoreline localities in Hawaii, although there 
is little field evidence of the basal groundwater being contaminated (Bowles 2000).

Interactions between various physical, chemical and biological reactions, together with the influence of transport processes and hydrogeological conditions, may facilitate a degree of purification in some groundwater systems (Matthes and Pekdeger 1981; Golwer 1983; Ford and Williams 1989). As with karst aquifers, however, the opportunities for this to occur in fissured or conduit lava aquifers are more limited due to relatively little rock surface being available for adsorption and ion exchange and for colonisation by micro-organisms. Evaporative removal of volatile organic compounds and pesticides is likely to be inhibited by rapid infiltration. Evidence of significant sediment throughput at Laufbalavatn amply demonstrates that physical filtration is likely to be limited, turbulent flow enabling long-distance penetration of particulate matter. Pathogenic bacteria and viruses are likely to be able to survive the short transmission times through aquifers of this type, especially given the likelihood of limited adsorption-desorption effects.

Lava surfaces may eventually become sealed by regolith without significant penetration of sediment underground, as evident from initial trends in Rauðsteinshellir and from the lack of alluvial sediments in lava tubes generally (Webb and others 1982). The degree of aquifer contamination risk is less obvious where lava flows are older, more weathered and buried, and where few data are available concerning lava-flow genesis and structure. Although recognition of the importance of endogenous emplacement mechanisms in some lava flows may be relatively recent and most recorded lava-tube caves occur in young lava flows, there is no reason to assume that endogenous flow mechanisms and lava-tube formation were not equally prominent in the emplacement of some older lavas (Self and others 1996), even if observation of structural detail is now impeded by the superimposition of younger bedrock units, unconsolidated sediments, or the accumulation of weathering residues. The hydrogeological significance of some lava-tube caves could even increase over time as weathering residues block vesicles and other small voids or sediment accumulates on cave floors, impeding infiltration. Persistence of large void systems may be suggested by bore yields, the topographic or geological position of some springs, spring recession characteristics, or suspended sediment in spring discharge which requires turbulent flow.

Although thick soil and sediment mantles may limit the entry of some pollutants into aquifers in ancient basalts, any fissured or conduit aquifers is likely to retain a degree of vulnerability. In karst areas the direct run-in contribution via sinkholes and point water sinks can aggravate water-quality deterioration (Wheeler and others 1989) but, even in a karst environment which contains numerous sinkholes, the largest quantities of nitrates and pesticides appear to be delivered to groundwater by diffuse infiltration (Hallberg 1985). In the Big Spring Basin in Iowa, USA, nitrate-nitrogen concentrations rose from $\sim 3 \mathrm{ppm}$ in the 1950s and 1960s to 9 ppm in 1982 and $10 \mathrm{ppm}$ in 1983
(Hallberg 1985). In an intensively cropped karstic catchment in Iowa, Wheeler and others (1989) recorded atrazine in over $70 \%$ of water samples taken from cave and stream sites. Nitrate-nitrogen concentrations were consistently much higher in the cave and stream samples than from wells which tapped deeper aquifers. They appear to have risen by nearly $40 \%$ in the 15 years between $1973-$ 1974 and 1985-1987. In the Dry Creek watershed of eastern Iowa, Wunder and Johnson (1995) found that temporal triazine concentration in well water correlated with surface water but found no similar link in nitrate concentrations. Working in an agricultural area in Kentucky, Currens (1995) found nitrate to be the most persistent groundwater contaminant, and consistently detected triazines (including atrazine) and other pesticides. These contaminants were generally below recommended maximum levels, but bacterial contamination typically exceeded limits for potable waters. The potential exists for similar situations in some older, covered lavas.

\section{Potential implications for aquifer management in older lava flows}

Original rock structure, the degree to which voids remain open, climatic factors, adequacy of geological knowledge and land use will all influence aquifer structure and function and their potential implications. This can be illustrated using several Australian lavas of varying age.

\section{Heard Island, southern Indian Ocean}

The youngest volcanic rocks in Australian territory occur on sub-Antarctic Heard Island in the southern Indian Ocean $\left(73^{\circ} 32^{\prime} \mathrm{E}, 53^{\circ} 06^{\prime} \mathrm{S}\right)$ where volcanic activity persists. They are poorly dated but construction of the main Big Ben Volcano $(2,745 \mathrm{~m})$ has occurred within the last $1 \mathrm{ma}$ and recent parasitic cones post-date 10 ka B.P. Rapid infiltration occurs into bare lavas at the foot of one parasitic cone, Mt Dixon, where no lava-tube caves are known but where tumuli and structures exposed in sea cliffs indicate endogenous lava emplacement (Fig. 17). Lava flows on Azorella Peninsula, which may be only centuries old but which are mantled by considerable aeolian sediment, retain little surface water. Despite an average 300 rain days annually and annual precipitation of $1,350 \mathrm{~mm}$, concentrated water flows and fluvial sediments are rare in the shallow lava-tube caves which are largely bypassed by infiltration. There is equally rapid infiltration into sediment-mantled lavas at nearby Saddle Point where large, unexplored cave entrances in inaccessible sea cliffs are probably drained lava tubes. Heard Island is an uninhabited Wilderness Reserve and World Heritage Area. Hence, any management implications of its lava aquifers relate primarily to the conservation of cave-dwelling biota, notably penguins and possible underground aquatic communities (Kiernan and McConnell 2000). Strict environmental protection protocols have been developed by the Australian Antarctic Division. 


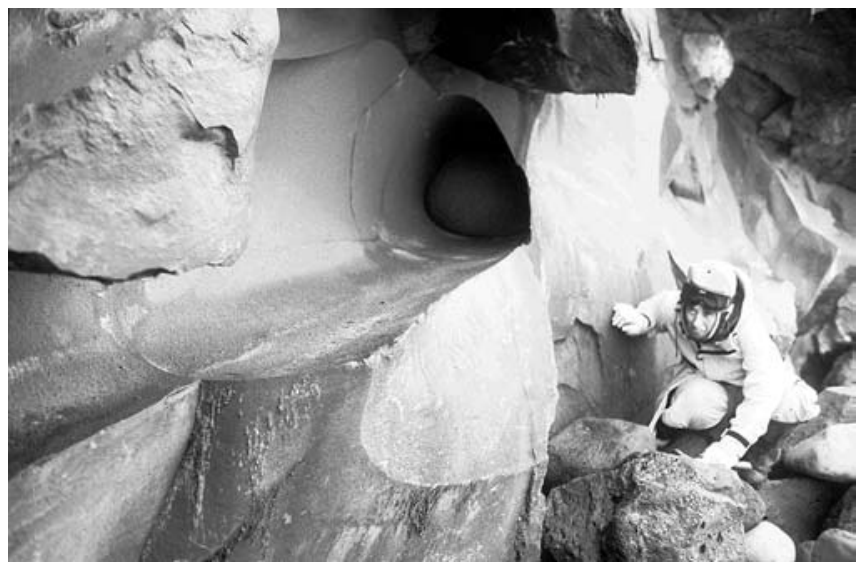

Fig. 17

Small, drained lava tube exposed in a sea cliff of dense lava at the foot of Mt Dixon, Heard Island. The visible obstruction is an egg-shell thin lava blister

\section{Undara, northern Queensland}

The $160-\mathrm{km}$-long Undara lava flow, the longest singlevolcano lava flow in the world, covers $1,550 \mathrm{~km}^{2}$. This basaltic flow was erupted $\sim 190$ ka B.p. from a crater $340 \mathrm{~m}$ wide and $48 \mathrm{~m}$ deep, the rim of which rises $20 \mathrm{~m}$ above the surrounding lava field, one of 160 vents in the $5,000-\mathrm{km}^{2}$ McBride Province (Atkinson and Atkinson 1995). In contrast to Heard Island, the environment at Undara $\left(144^{\circ} 18^{\prime} \mathrm{E}, 18^{\circ} 12^{\prime} \mathrm{S}\right)$ is seasonally arid, $80 \%$ of the mean annual precipitation $(794 \mathrm{~mm})$ falling between December and March. The regolith is generally very thin. One cave near the edge of the lava flow (Fig. 18) descends to a semipermanent lake, whereas others nearby become flooded during major rainfall events when water emerges through their floors. Thin crusts of carbonate precipitate from this water, sometimes forming micro spring-mounds. Sediment has been washed into some caves by concentrated runoff from the granite margins. Some caves took 13 months to drain after a major flood in 1991. Moist conditions allow rainforest to persist in collapse entrances in this otherwise arid setting. The prominence of water in these caves is attributable to the Undara lava typically being no more than $5 \mathrm{~m}$ thick at the edges and attaining a general maximum of $\sim 20 \mathrm{~m}$. It is perched upon granite, in contrast to Heard Island where the lavas extend below sea level. Aridity has influenced human use of this area, with one cave located close to a kipuka long known as the location of an important spring which emerges from the cave wall. Until recently an outback pastoral holding, part of the area has now become a national park and tourist destination. The resort utilises groundwater from the lava aquifer, which is sufficiently carbonate-rich to cause calcification of heating elements (V. Speedie, personal communication). Stringent safeguards are in place to protect the aquifer.

\section{Newer Volcanics Province, western Victoria, Australia}

Many lava-tube caves are known in temperate western Victoria. The most celebrated occur in lavas 7-8 ka old but

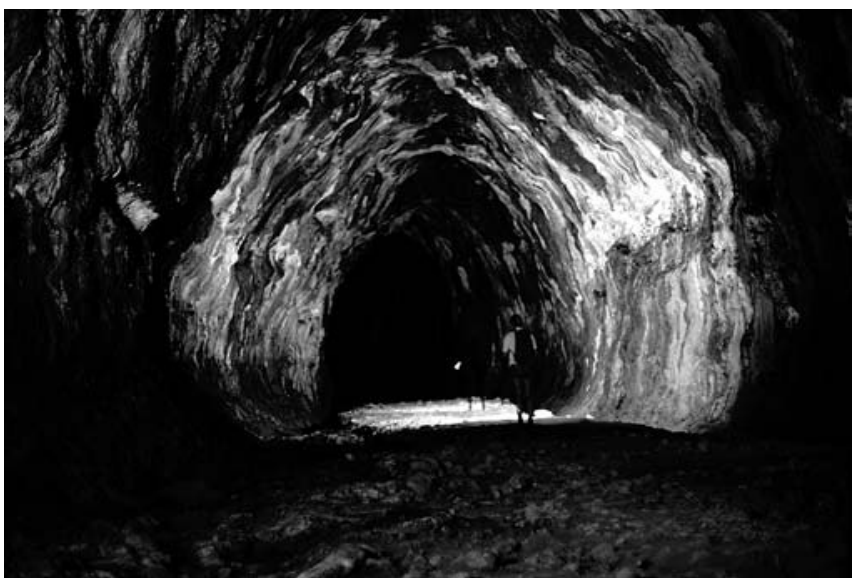

Fig. 18

Barkers Cave, Undara, Queensland, Australia, is up to $19.8 \mathrm{~m}$ wide and $13.5 \mathrm{~m}$ high

others occur in lava flows up to several million years old (Webb and others 1982; Webb 1997). Some younger flows remain fresh but older lavas are weathered to as deep as $10 \mathrm{~m}$ and have been laterised. The lavas are on average $50 \mathrm{~m}$ thick and overlie predominantly Tertiary rocks including limestones, further complicating aquifer interpretation. Groundwater from aquifers in basalt, scoria and tuff of Miocene-Holocene age is used for stock watering, irrigation and domestic purposes, and contributes to water supplies for the towns of Penshurst, Dunkeld, Caramut, Mortlake, Streatham and Skipton. These aquifers are generally $<70 \mathrm{~m}$ thick (maximum $\sim 120 \mathrm{~m}$ ), and bores generally yield $<2,160 \mathrm{l} /$ day (maximum $\sim 86,400 \mathrm{l} /$ day). Principal recharge is via the Newer Volcanics and especially the 'stony rise country', rather than from adjacent highlands, and discharge occurs southwards into creeks and lakes. Salinity levels vary in the range $<100-8,000$ TDS but are mostly $>2,000$ away from scoria cones and stony rises (Leonard 1992), highlighting the importance of protecting these recharge areas.

Rubbish dumping has been recognised as a threat to the lake in biologically and mineralogically important Skipton Cave (Webb and others 1982; Fig. 19). Stanley (1992) reported that discharge from St Enochs Spring, which is used to boost the reservoir for the town of Skipton, had nitrate (as N) and Escherichia coli levels which commonly exceeded the recommended World Health Organisation limits of $10 \mathrm{mg} / \mathrm{l}$ and $0 / 100 \mathrm{ml}$ respectively. Accession of nitrate to groundwater is generally regarded as a recent phenomenon related to human activities. Variability in nitrate levels arises due to land-use practices, local soils and vegetation, climate, urban and other pollution (Lawrence 1983). Although relatively high nitrate levels do not necessarily indicate pollution, their co-presence with E. coli at St Enochs Spring suggests contamination. In this case contamination was suggested to be of only local origin, on the assumption that E. coli was unlikely to survive in groundwater (Stanley 1992). However, such an assumption may not always be warranted in a fissured or conduit aquifer where rapid, long-distance transmission of 


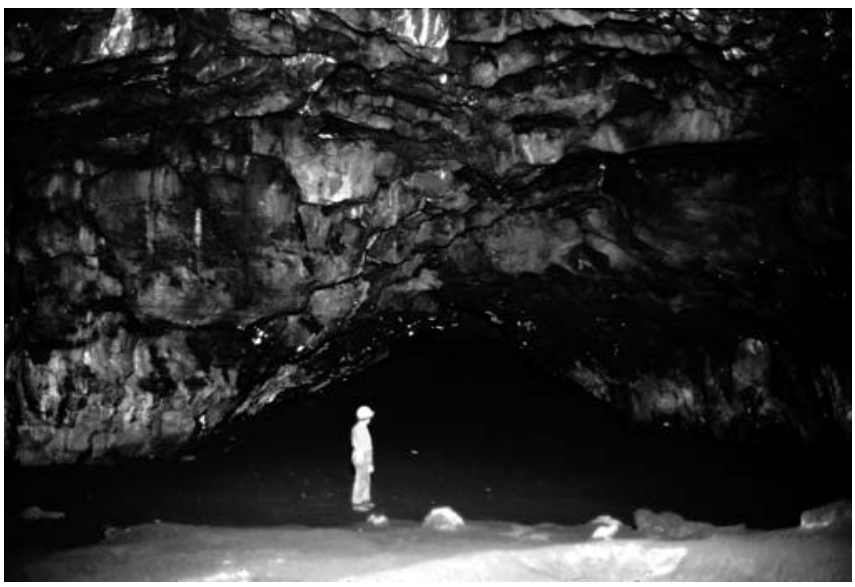

Fig. 19

Chamber 50-60 m long, $20 \mathrm{~m}$ wide and 8-10 $\mathrm{m}$ high in Skipton Cave, western Victoria

pollutants is possible. Bayne (1998) found that during 1993-1994 N concentrations from Ettrick Spring, located in a dairy-farm area, were $8.0-16.1 \mathrm{mg} / \mathrm{l}$. From the relationship between groundwater and soil concentrations, he suggested cows return nitrogen at protected 'campsites' on the pasture and that it involves both matrix flow and preferential flow. For reasons which are unclear, groundwater N levels declined between 1975-1976 and 1993-1994. Bayne (1998) suggests it may be related to a natural decline in clover having decreased nitrogen entry to the soil system by nitrogen fixation associated with clovers.

Pollution of basalt aquifers due to percolation from waste-disposal sites has also occurred in a more urban setting in the western suburbs of Melbourne (Riha 1976, 1978). An unconfined aquifer in basalt and other rocks on the western outskirts of the city is contaminated by organic and inorganic compounds. A conceptual model of groundwater flow proposed by Finegan and others (1998) suggests flow in the basaltic aquifer is likely to be through flow tops and bases, intercalated fluvial sediments, and fractured and jointed lava flows. An eroded tumulus on the foreshore in the western suburb of Williamstown indicates endogenous lava emplacement, at least locally.

\section{Tasmania}

Lavas erupted from over 120 identified and inferred centres cover $\sim 400 \mathrm{~km}^{2}$ of Tasmania, some individual flows travelling 40-50 km. In north-western Tasmania interfluves were overtopped to form plains exceeding $250 \mathrm{~km}^{2}$. Pyroclastic units occur between flows $50-180 \mathrm{~m}$ thick giving total sequence thicknesses of up to $400 \mathrm{~m}$ (Sutherland 1989). The oldest lavas, in north-eastern Tasmania, date from 59-46 Ma, the youngest occur along the northwestern coast (16-8 Ma) whereas lavas on the Central Plateau are of Oligocene-early Miocene age (35-22 Ma; Sutherland and Wellman 1986). Given Oligocene glaciation in Tasmania, coincident with the onset of glaciation in Antarctica (Macphail and others 1993), probable glacially striated rock surfaces beneath the basalt on the Central Plateau and associated aquagene sequences (Sutherland and Hale 1970) suggest a somewhat Icelandic environment at the time of some eruptions. Erosion has greatly modified the original volcanic topography, leaving some valley flows now capping interfluves over $500 \mathrm{~m}$ high between twin streams. Incongruence between present-day groundwater gradients and the hydraulic gradients to which lava flow responded and which influenced initial groundwater trajectories are likely to have influenced sedimentation within void systems.

These basalts amply illustrate potential difficulties in accurately interpreting aquifers in ancient lavas which are very thickly mantled by sediment or weathering residues. Springs occur at the base of some lava flows and others may be explicable as discharges from pillow lavas or pyroclastic interbeds. Bore productivity is consistent with aquifers being most productive where voids are least affected by weathering residues or sediment. The very weathered, $60-70 \mathrm{~m}$ thick Moriarty Basalt gives average yields of $\sim 7,800 \mathrm{l} / \mathrm{h}$ and maximum yields of up to 18,000 $\mathrm{l} / \mathrm{h}$, but nearly $50 \%$ of bores fail. It overlies $75 \mathrm{~m}$ of Oligocene sand, unimportant as an aquifer, which in turn overlies the relatively unweathered Thirlstane Basalt, a 160-175 $\mathrm{m}$ thick succession of thin lava flows which yield $12,000-24,000 \mathrm{l} / \mathrm{h}$, with some deeper bores yielding $48,000 \mathrm{l} / \mathrm{h}$, and in one case $78,000 \mathrm{l} / \mathrm{h}$. Such basalt aquifers have customarily been interpreted to be porous media (Cromer 1979; Scanlon and others 1990). No accessible lava-tube caves have been recorded in these old, deeply weathered and sediment-covered Tasmanian lavas in which the largest reported cavities are small vughs, but structures indicative of endogenous emplacement have been reported from the Central Plateau (Sutherland and Hale 1970).

Surface runoff and some streams fed by springs are often very turbid but confident attribution of a deep subsurface source to any sediment flux in streams emerging through regolith can be difficult. Study of one continuously cropped slope, using ${ }^{137} \mathrm{Cs}$, has indicated a net annual soil loss of 19.3 t/ha (Loughran and others 1992). Notwithstanding deficiencies in land management on some properties, there is increasing reliance by some Tasmanian farmers on the isolated island's 'clean, green' marketing image. Producers of organic products for export must meet rigorous criteria to obtain continued certification of their enterprises. With increasing awareness of environmental problems and the rapid spread of intensively managed tree plantations, concerns regarding the potential for chemical use to impinge on groundwater quality are increasingly being expressed by organic producers and others in the community. The possibility of rapid groundwater transmission through fissured or conduit aquifers and karst-like vulnerability suggests a need for caution and research. Although the economic and social consequences of contamination of individual wells or springs may be small relative to government or corporate budgets, they may represent severe hardship for individuals and families. 


\section{Conclusion}

Despite increasing recognition of the importance of endogenous lava emplacement processes, re-evaluation of some lavas previously interpreted as flood basalts remains in its infancy. Updating of groundwater models is required because evidence from very young lava flows indicates that structures produced by endogenous processes of lava emplacement offer important groundwater reservoirs, and efficient and speedy passage for groundwater flows. Similar structures may persist even in very old lava flows. Their potential vulnerability suggests greater research into the structure and function of some basalt aquifers is warranted. Should groundwater contamination occur, it may have significant health and economic implications both for individual bore users and for the broader community, and especially for producers of organic crops who must meet stringent requirements with respect to chemical use and contamination on their properties. Thus, there are sound reasons for more research and a more conservative and protective approach to the management of some basalt aquifers than may presently be the norm in some areas.

Acknowledgements We are grateful to our fellow members of the Laki Underground expeditions 2000 and 2001 with whom we explored and mapped the lava tubes beside Laufbalavatn, and to the sponsors and supporters of those expeditions, including the Royal Geographical Society, the Carnegie Trust for Scottish Universities, The Royal Scottish Geographical Society, the Ghar Parau Foundation, the British Cave Research Association, and members of the Icelandic Speleological Society (Hellarannsóknafélag Islands). We also thank Ed Waters for assistance with Fig. 8a, and Paul Cheetham for the magnetic survey data upon which Fig. 13 is based. Icelandic cave maps and geophysical images have been adapted from Laki Expedition reports 2000 and 2001 with permission of the authors. Work on Heard Island was made possible by an Australian Antarctic Science grant.

\section{References}

Atkinson A, Atkinson V (1995) Undara volcano and its lava tubes. Anne \& Vernon Atkinson, Brisbane

Bayne PJM (1998) Occurrence of nitrate in soil and groundwater in the Corangamite area, western Victoria. In: Weaver TR, Lawrence CR (eds) Groundwater: sustainable solutions. Proc Int Groundwater Conf, University of Melbourne, 8-13 February 1998, Int Assoc Hydrogeol, pp 407-412

Bowles P (2000) The basal groundwater and lava tubes, or, where's the meat? In: Program Abstr Vol Conf Lava Tubes and Groundwater Contamination, Hilo, 2 August 2000. Hawaii Chap Natl Speleol Soc, p 4

Crawford RL (1992) Biota of volcanic caves: an introduction. In: Halliday WR (ed) Proc 3rd Int Symp Vulcanospeleology, Bend, Oregon, 1982. Int Speleol Foundation, Seattle, pp 37-41

Cromer WC (1979) Results of drilling for water in the Devonport - Port Sorell - Sassefrass area, 1967/79, and selection of future bore sites. Tasmanian Dept Mines Rep 1979/16

Currens JC (1995) Mass flux of agricultural nonpoint-source pollutants in a conduit-flow dominated karst aquifer, Logan County, Kentucky. In: Beck BF (ed) Karst geohazards. Balkema, Rotterdam, pp 179-181
Davis SN, De Wiest RJM (1966) Hydrogeology. Wiley, New York Fetter CW (1988) Applied hydrogeology. McMillan, New York Finegan JM, Weaver T, Lawrence C (1998) Conceptual model of groundwater flow in a basaltic aquifer system near Melbourne, Australia. In: Weaver TR, Lawrence CR (eds) Groundwater: sustainable solutions. Proc Int Groundwater Conf, University of Melbourne, 8-13 February 1998, Int Assoc Hydrogeol, pp 143150

Ford DC, Williams P (1989) Karst hydrology and geomorphology. Unwin Hyman, London

Golwer A (1983) Underground purification capacity. In: Ground water in resources planning. Proc Koblenz Symp. UNESCO, Int Assoc Hydrol Sci Publ 42:1063-1072

Grimes K (1999) Volcanic caves and related features in western Victoria. Cave Manage Australasia 13:148-151

Halihan T, Wicks CM (1998) Modeling of storm responses in conduit flow aquifers with reservoirs. J Hydrol 208:82-91

Hallberg GR (1985) Agricultural chemicals and groundwater quality in Iowa: status report 1985 . Iowa State University, Ames Halliday WR (1995) Resources, values and management of Puna Caves. Hawaii Speleol Surv Natl Speleol Surv Rep 95-01

Halliday WR (1998a) Hollow volcanic tumulus caves of Kilauea Caldera, Hawaii County, Hawaii. Int J Speleol 27B(1/4):95105

Halliday WR (1998b) Sheet flow caves of Kilauea Caldera, Hawaii County, Hawaii. Int J Speleol 27B(1/4):107-112

Halliday WR (2000) Raw sewage and solid waste dumps in Big Island lava tube caves: a public health menace? In: Program Abstr Vol Conf Lava Tubes and Groundwater Contamination, Hilo, 2 August 2000. Hawaii Chap Natl Speleol Soc, p 6

Halliday WR (2001) Living with pseudokarst. In: Rea T (ed) Proc 1999 National Cave and Karst Management Symp. Southeastern Cave Conservancy, Chattanooga, pp 91-95

Heming RF (1979) Natural bridges in basalt lavas, Northland, New Zealand. N Z J Geol Geophys 22(2):239-243

Hon K, Kauahikaua J, Delinger R, McKay K (1994) Emplacement and inflation of pahoehoe sheet flows: observations and measurements of active lava flows on Kilauea Volcano, Hawaii. Geol Soc Am Bull 106:351-370

Howarth FG (1996) A comparison of volcanic and karstic cave communities. In: Oromi P (ed) Proc 7th Int Symp Vulcanospeleology, Canary Islands, November 1994. Federacion Espanola Espeleologia, Federacion Caria Espeleologia, pp 63-68

Johnson KL, Wright GMcK, Ashton DH (1968) Ecological studies of Tunnel Cave, Mt Eccles. Victoria Nat 85:350-356

Johnson Division (1966) Groundwater and wells. Johnson Division, Universal Oil Products Co, St Paul, Minnesota

Kaldal I (2001) Skaftá - Hverfisfljót. Jökulhaupið sumarið 1995. Orkustofnun Rannsóknasvið

Kambesis P (1995) Kazumura cave project - 1995. Natl Speleol Soc News 53(11):300-303

Kambesis P (2000) Streamflow in Kaumana Cave. In: Program Abstr Vol Conf Lava Tubes and Groundwater Contamination, Hilo, 2 August 2000. Hawaii Chap Natl Speleol Soc, pp 6-7

Kiernan K (1982) Volcanokarst in the culture and landscape of Easter Island. In: Halliday WR (ed) Proc 3rd Int Symp Vulcanospeleology, Bend, Oregon, 1982. Int Speleol Foundation, Seattle, pp 85-91

Kiernan K, McConnell A (2000) Management considerations for the Heard Island lava tube caves. Pap Proc R Soc Tasmania 133(2):13-22

Kulkarni H, Deolankar SB, Lalwani A, Joseph B, Pawar S (2000) Hydrogeological framework of the Deccan basalt groundwater systems, west-central India. Hydrogeol J 8(4):368-378

Lawrence CR (1983) Nitrate-rich groundwater of Australia. AGPS, Canberra, Aust Water Res Council Tech Pap 79

Leonard J (1992) An overview of Victoria's groundwater resources. Dept Water Resources, Melbourne, Background Rep S3 
Loughran RJ, Curtis SJ, Elliott GL, Campbell BL, Kiernan K, Temple-Smith MG (1992) A reconnaissance survey of soil erosion in Australia. In: Haskins PG, Murphy BM (eds) People protecting their land. Proc 7th Int Soil Conservation Organisation Conf, Sydney, 27-30 September 1992, Soil Conservation Organisation, pp 52-63

Macphail MK, Colhoun EA, Kiernan K, Hannan DG (1993) Global climates in the Antarctic region during the late Palaeogene: evidence from northwest Tasmania, Australia. Geology 21:145-148 Matthes G, Pekdeger A (1981) Concepts of a survival and transport model of pathogenic bacteria and viruses in groundwater. In: van Duijvenbooden W, Glasbergen P, van Lelyveld H (eds) Quality of groundwater. Proc Int Symp, Noordwijikerhout, The Netherlands, 23-27 March 1981, Studies in Environmental Science 17, pp 23-27

Maxwell GB, Hacket JE (1963) Applications of geohydrologic concepts in geology. J Hydrol 1:33-46

Middleton G (2000) Groundwater and pollution in Mauritian lava caves. In: Program Abstr Vol Conf Lava Tubes and Groundwater Contamination, Hilo, 2 August 2000. Hawaii Chap Natl Speleol Soc, pp 4

Middleton G, Halliday WR (1997) Caves of the Republic of Mauritius, Indian Ocean. In: Proc 12th Int Congr Speleology, Switzerland, 1997, vol 1, pp 437-440

Middleton G, Kiernan K (2002) The Laki 2000 Expedition: Skaftáreldahraun and Hallmundarhraun, Iceland, AugustSeptember 2000. J Sydney Speleol Soc 45:93-117

Ollier CD (1969) Volcanoes. ANU Press, Canberra

Ollier CD, Brown MC (1965) Lava caves of Victoria. Bull Volcanol 28:215-229

Ollier CD, Zarriello P (1979) Pe'ape'a Cave, western Samoa. Trans BCRA 6(3):133-142

Hernandez J, Oromi P (1996) New discoveries of lava tubes related to Cueva del Viento in Icod de los Vinos (Tenerife, Canary Islands). In: Oromi P (ed) Proc 7th Int Symp Vulcanospeleology, Canary Islands, November 1994. Federcion Española Espeleologia, Federacion Canaria Espeleologia, pp 59-61

Riha M (1976) Hydrochemical effects of waste percolation on groundwater in basalt near Fotscray, Victoria. Dept Miner Energy Victoria Rep 1976/86

Riha M (1978) Investigation of the hydrogeology and groundwater pollution in the basalt aquifer system, west of Melbourne. Dept Miner Energy Victoria Rep 1978/40

Scanlon A, Fish GJ, Yaxley ML (1990) Behind the scenery. Education Dept, Hobart

Self S, Thordarson Th, Keszthelyi L, Walker GPL, Hon K, Murphy MT, Long P, Finnemore S (1996) A new model for emplacement of Columbia River basalts as large, inflated pahoehoe lava flow fields. Geophys Res Lett 23(19):2689-2692

Sen Z (1995) Applied hydrogeology - for scientists and engineers. Lewis, Boca Raton

Shaw HR, Swanson DA (1970) Eruption and flow rates of flood basalts. In: Gilmour EH, Swanson DA (eds) Proc 2nd Columbia Basalt Symp, Cheney. Eastern Washington State College Press, pp 271-299
Stanley DR (1992) Groundwater usage and resource potential along the northern margin of the Basalt Plains, Western Victoria. Rural Water Comm Victoria Invest Branch Rep 1992/6

Stearns HT, McDonald GA (1946) Geology and groundwater resources of the island of Hawaii. Territory Hawaii Div Hydrogr Bull 9

Sutherland FL (1989) Tertiary volcanism. In: Burrett CF, Martin EL (eds) Geology and mineral resources of Tasmania. Geol Soc Aust Spec Publ 15:383-386

Sutherland FL, Hale GEA (1970) Cainozoic volcanism in and around Great Lake, Tasmania. Pap Proc R Soc Tasmania 105:151-176

Sutherland FL, Wellman P (1986) Potassium argon ages of Tertiary volcanic rocks, Tasmania. Pap Proc R Soc Tasmania 120:77-86

Thordarson Th, Self S (1998) The Laki (Skaftár Fires) and Grímsvötn eruptions in 1783-1785. Bull Volcanol 55:233-263

Todd DK (1980) Groundwater hydrology. Wiley, New York Walker GPL (1991) Structure, and origin by injection of lava under surface crust, of tumuli, 'lava rises', 'lava rise pits", and 'lava inflation clefts' in Hawaii. Bull Volcanol 53:546-558

Webb JA (1997) Skipton lava cave, Victoria, Australia. In: Hill C, Forti P (eds) Cave minerals of the world. Natl Speleol Soc, Huntsville, Alabama, pp 331-335

Webb JA, Joyce EB, Stevens NC (1982) Lava caves of Australia. In: Halliday WR (ed) Proc 3rd Int Symp Vulcanospeleology, Bend, Oregon, 1982. Int Speleol Foundation, Seattle, pp 37-41

Werner S, Kempe S, Elhard R (2000) Thiscave and Thatcave: erosional caves in the lava of Mauna Kea. In: Program Abstr Vol Conf Lava Tubes and Groundwater Contamination, Hilo, 2 August 2000. Hawaii Chap Natl Speleol Soc, p 8

Wheeler BJ, Alexander EC, Adams RS, Huppert GN (1989) Agricultural land use and groundwater quality in the Coldwater Cave groundwater basin, upper Iowa River karst region, USA. Part II. In: Gillieson DS, Smith DI (eds) Resource management in limestone landscapes: international perspectives. Dept Geogr Oceanogr, University College, Aust Defence Force Acad, Canberra, Spec Publ 2, pp 249-260

Wood C, Cheetham P, Watts R, Randall N (2001) Laki Underground 2000: the Bournemouth/Dundee universities joint expedition to Iceland. School of Conservation Sciences, Bournemouth University, UK

Wood C, Watts R, Cheetham P (2002) Laki Underground 2001: report of the UK expedition to the Skaftereldahraun, $S$ Iceland, July/Aug. 2001. Bournemouth University, UK (in press)

Wunder DB, Johnson JK (1995) Private well-water quality of the karst and agricultural dry creek watershed in eastern Iowa. Implications for appropriate management. In: Beck BF (ed) Karst geohazards. Balkema, Rotterdam, pp 199-203 